\title{
Characterization of gangliosides from Ehrlich ascites tumour cells and their variants*
}

\author{
ETSU KISHIDA $\$$ and IRWIN J. GOLDSTEIN§ \\ Department of Biological Chemistry, University of Michigan, Ann Arbor, Michigan 48109, USA
}

Received 4 April 1995, revised 16 August 1995

Differences in the nature of the gangliosides present in two types of Ehrlich ascites tumour (EAT) cells, the adherent and non-adherent EAT cells, were studied. Gangliosides were isolated by DEAE Sephadex column chromatography and analysed by high-performance thin-layer chromatography (HPTLC). The non-adherent EAT (na-EAT) cells which grow in the peritoneal cavity of mice were selected for growth on basement membrane and tissue culture plastic to give the adherent EAT (a-EAT) cells. na-EAT cells contained 1.57 nmol lipid-bound sialic acid per mg protein and at least 12 different gangliosides, including major gangliosides such as GM3, GM2, GM1, GD3, GD1a and GT1b. On the other hand, the ganglioside pattern of a-EAT cells differed significantly from that of na-EAT cells, both quantitatively and qualitatively. The content of lipid-bound sialic acid in a-EAT cells was only 0.24 nmol per mg of protein. The gangliosides in a-EAT cells were characterized as GD1a and trisialogangliosides and, significantly, a-EAT cells did not contain monosialogangliosides. Neutral glycolipids were isolated from both cell lines and their patterns were compared. In contrast to the gangliosides pattern, their neutral glycolipid patterns were similar. Glucosylceramide and lactosylceramide were the major components in both types of cells. In addition to na- and a-EAT cells, a-EAT cells were passaged in mice by intraperitoneal injection, giving rise to a third variant ( $\mathrm{c} / \mathrm{m}$ EAT cells). We analysed the gangliosides in $\mathrm{c} / \mathrm{m}$ EAT cells to determine whether there was a change in the ganglioside pattern found in na-EAT cells. After repeated passage of $\mathrm{c} / \mathrm{m}$ EAT cells in mice, the pattern of gangliosides shifted to that of na-EAT cells. Alterations of ganglioside composition may be associated with the growth environment of the murine peritoneal cavity; alternatively, a selection process may have occurred.

Keywords: Ehrlich ascites tumour cells, ganglioside, glycolipid

Abbreviations: EAT cells, Ehrlich ascites tumour cells; na-EAT cells, non-adherent EAT cells; a-EAT cells, adherent EAT cells; c/m EAT cells, cultured a-EAT cells passaged in mice; HPTLC, high-performance thin-layer chromatography; PBS, $10 \mathrm{mM}$ phosphate-buffered saline, $\mathrm{pH} 7.2$, containing $0.15 \mathrm{M} \mathrm{NaCl}$; EDTA, ethylenediaminetetraacetic acid; TFA, trifluoroacetic acid; TG, thioglycollate; Cer, ceramide ( $N$-fatty acyl sphingosine); GM3, NeuAc $\alpha 2-3$ Gal $\beta 1-4 G 1 c-C e r ; ~ G M 2$, GalNAc $\beta 1-4(N e u A c \alpha 2-3)$ Gal $\beta 1-4 G l c-C e r ; ~ G M 1 a, G a l \beta 1-3 G a l N A c \beta 1$ -

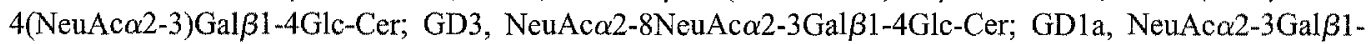

3 GalNAc $\beta 1-4($ NeuAc $\alpha 2-3)$ Gal $\beta 1-4$ Glc-Cer; GT1b, NeuAc $\alpha 2-3$ Gal $\beta 1-3 G a l N A c \beta 1-4(N e u A c \alpha 2-8 N e u A c \alpha 2-3) G a l \beta 1-$ 4Glc-Cer; LacCer, Gal $\beta 1-4 \mathrm{Glc}-\mathrm{Cer}$; Gb3, Gal $\alpha 1-4 \mathrm{Gal} \beta 1-4 \mathrm{Glc}-\mathrm{Cer}$; Gb4, GalNAc $\beta 1-4 \mathrm{Gal} \alpha 1-4 \mathrm{Gal} \beta 1-4 \mathrm{Glc}-\mathrm{Cer}$.

\section{Introduction}

Ehrlich ascites tumour cells (EAT cells) are routinely grown in the peritoneal cavity of mice. In previous studies of EAT cells from our laboratory $[1,2]$, the structural

\footnotetext{
* This paper is dedicated to my esteemed colleague, Sen-itiroh Hakomori on the occasion of his 65 th birthday.

$\$$ Present address: Department of Life and Health Sciences, Hyogo University of Teacher Education, Hyogo 673-14, Japan.

$\S$ To whom correspondence should be addressed.
}

features of the carbohydrate moiety present in cell surface glycoproteins containing terminal non-reducing $\alpha$-linked galactosyl groups were described. During the course of studies on the cell surface glycoconjugates of EAT cells and their possible physiological role(s), we developed an EAT cell variant system in which EAT cells had been selected to grow in cell culture, and were capable of attaching to the surface of culture flasks. These cells were referred to as adherent EAT (a-EAT) cells to distinguish them from the ascites-grown cells, which were referred to as non-adherent EAT (na-EAT) cells. Besides differences 
in adhesion ability, these two lines of EAT cells exhibited a difference in tumourigenicity [3]. Differences in cell surface glycoproteins and in laminin and fibronectin synthesis between these two EAT cell lines were studied using three different lectins as probes [4]. We showed that both EAT cell lines express surface glycoproteins reactive with Maackia amurensis lectin (MAL) [5,6] and Griffonia simplicifolia isolectin (GS I-B4) [7]. However, only a-EAT cells react with elderberry (Sambucus nigra) bark lectin (SNA) [8] suggesting that there are some differences in the sialylation of cell surface carbohydrate moieties between the two EAT cell lines. In connection with these studies, we also showed a-EAT cells exhibited a selective increase in the activity of $\alpha-2,6-\mathrm{N}$-linked sialyltransferase activity [9]. Recent reports indicate that there is an increase in the N-linked $\alpha-2,6$ - but not $\alpha$-2,3-sialyltransferase in human colorectal cancer compared to poorly metastic tissues [10]. These results suggested the EAT cell system may serve as a good experimental model for the investigation of sialyltransferases and their cell surface sialylated products in relation to cancer, metastasis, and cell-cell interactions.

As an extension of these studies on glycosylation and cell adhesion, we are interested in the glycosylation patterns of glycolipids in EAT cells, since alterations in glycolipid composition have been observed in a variety of experimental tumours as well as human cancer $[11,12]$. In particular, gangliosides are important constituents of cellular membrane and are considered to play a role in cellular interactions, growth control or adhesiveness of cells $[13,14]$. In this report, we described differences that exist in the ganglioside patterns between two EAT cell lines. In addition to the analysis of the gangliosides in na- and a-EAT cells, we studied the gangliosides present in a-EAT cells that had been reintroduced into and passaged in the peritoneal cavity of the mice in order to determine whether there is a change in the pattern found in na-EAT cells.

\section{Materials and methods}

\section{Materials}

CD-1 female mice, 25-30 g, were obtained from Charles River, Portage, MI. DEAE Sephadex A-25 and neuraminidase (Vibrio chlorae) were purchased from Sigma. Ceramide-glycanase (Leech, Marobdella decora) was from V-LABS, Inc, LA. Gangliosides and neutral glycosphingolipids used as standards were from Matreya Inc. High-performance thin-layer chromatography (HPTLC) plates were from E. Merck, Darmstadt, FGR.

\section{Maintenance and preparation of na-EAT cells}

EAT cells were maintained by weekly intraperitoneal injection of $0.4 \mathrm{ml}$ of ascites fluid (approximately $4 \times 10^{7}$ cells) into CD-1 female mice. The ascites cells and fluid were centrifuged at $1000 \mathrm{rpm}$ (International portable refrigerated centrifuge, Model PR-2) and separated into supernatant and cell fractions. In order to remove contaminating intact and broken cells, the supernatant solution was centrifuged at $5000 \mathrm{rpm}$ for $10 \mathrm{~min}$. The cell-free supernatant was lyophilized and used as an ascites fluid fraction. The cells were washed repeatedly with PBS.

\section{a-EAT cell culture}

a-EAT cells, selected from the ascite EAT cells [3] were cultured in $75 \mathrm{~cm}^{2}$ culture flasks containing Dulbecco's modified Eagle's medium (DMEM) (GIBCO) and 10\% fetal bovine serum (GIBCO). Cells were subcultured weekly. a-EAT cells were harvested using a buffer containing $5 \mathrm{mM}$ EDTA, were washed three times with PBS, and were stored at $-20{ }^{\circ} \mathrm{C}$ until use.

\section{Preparation of $\mathrm{c} / \mathrm{m}$-EAT cells}

A third variant of EAT cells was derived by intraperitoneal injection of the a-EAT cells (approximately $4 \times 10^{7}$ cells) into CD-1 mice and continued passage of the resulting ascitic tumour cells. This variant was designated as cultured cells grown in mice (c/m-EAT cells). The first passaged cells were designated $\mathrm{c} / \mathrm{m} 1$. c/m 2 EAT cells were a-EAT cells that were reintroduced into mice and passaged two times, etc. The cell fractions were prepared in the same manner as na-EAT cells.

\section{Preparation of thioglycollate (TG)-stimulated ascites fluid}

TG-stimulated ascites fluid was obtained from mice that had been injected intraperitoneally with $2 \mathrm{ml}$ of $3 \%$ solution of Brewer's modified TG medium (Becton Dickinson Microbiology systems, MD) prepared according to the manufacturer's instructions. Three to 4 days after the TG stimulation, the mice were killed, after which $3 \mathrm{ml}$ of PBS was injected into the peritoneal cavity. The ascites fluid (approximately 3-4 ml per mouse) was withdrawn and centrifuged to remove the peritoneal cells. The supernatant was lyophilized and subjected to glycolipid extraction.

\section{Extraction and subsequent fractionation of glycolipids}

Packed cells $(10 \mathrm{ml})$ were extracted with $35 \mathrm{ml}$ of isopropanol:hexane:water $(55: 25: 20, \mathrm{v} / \mathrm{v})$ by sonication for $5 \mathrm{~min}$ and centrifuged. The pellet was extracted again with $35 \mathrm{ml}$ of the same solvent. Subsequently the residue was extracted by sonication for $5 \mathrm{~min}$ in $35 \mathrm{ml}$ of chloroform:methanol (2:1). Finally, the residue was extracted with $35 \mathrm{ml}$ of chloroform:methanol (1:2) containing $5 \%$ water by sonication for $5 \mathrm{~min}$. The extracts were combined, evaporated to dryness, dissolved in $60 \mathrm{ml}$ of chloroform:methanol (2:1), and partitioned according to 
the method of Folch [15]. The glycolipids in the upper phase of the Folch partition were subjected to DEAESephadex A-25 column chromatography. The neutral glycolipids were eluted with chloroform:methanol:water (30:60:8). Gangliosides were separated into mono-, di-, and trisialogangliosides fractions by stepwise elution with $0.015,0.15$, and $0.45 \mathrm{M}$ ammonium acetate in methanol, respectively. The final isolation of individual gangliosides was performed by preparative TLC with precoated Silica Gel 60 plates (E. Merck) by solvent system A (see below). Lipid extracts in the lower phase were subjected to saponification, acetylation, and fraction by Silica gel column chromatography [16]. The glycolipid fractions were combined and evaporated. In order to remove contaminents from the glycolipid fractions, the glycolipids were subjected to Silica gel column chromatography a second time, and fractionated by stepwise elution with chloroform:methanol $(4: 1,1: 1$ and $1: 3, \mathrm{v} / \mathrm{v})$ and methanol [17]. Glucosyl ceramides and other glycolipids were recovered in the chloroform:methanol (4:1 and 1:1) fractions, respectively.

Gangliosides and neutral glycolipids were analysed by HPTLC. The following solvent systems were used: A, chloroform:methanol:0.25\% $\mathrm{KCl} \quad(50: 40: 10) ; \mathrm{B}$, chloroform:methanol:water (65:25:4); C, chloroform: methanol:water (65:35:8). Gangliosides and neutral glycosphingolipids were visualized by spraying with the resorcinol-hydrochloric acid reagent [18] and the orcinol reagent [19], respectively.

\section{Quantitative determination of gangliosides}

Gangliosides were determined by the resorcinol assay [18]. The proportion of individual gangliosides in a TLC plate was quantified by densitometry using an Apple Macintosh Centris 650 computer and NIH Image program (NIH Image 1.49).

\section{Characterization of isolated gangliosides}

The carbohydrate compositions were analysed by Dionex HPLC. A ganglioside, approximately $1 \mathrm{nmol}$, was hydrolysed with $2 \mathrm{M}$ trifluoroacetic acid for $4 \mathrm{~h}$ at $100^{\circ} \mathrm{C}$. The hydrolysate was subjected to HPLC and eluted with $8 \mathrm{mM}$ $\mathrm{NaOH}$. Gangliosides were assayed by neuraminidase hydrolysis in $100 \mu 1$ of $20 \mathrm{mM}$ tris-maleate buffer $(\mathrm{pH}$ 6.5) containing $4 \mathrm{mM} \mathrm{CaCl}_{2}$ and $0.5 \%$ Triton $\mathrm{X}-100$ at $37^{\circ} \mathrm{C}$ overnight. Chemical desialylation of gangliosides was performed by incubation in $2 \%$ acetic acid at $100{ }^{\circ} \mathrm{C}$

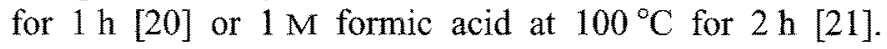
Ceramide-glycanase hydrolysis was conducted according to $\mathrm{Li}$ et al. [22]. The incubation mixture contained ganglioside, $10 \mathrm{nmol}$; sodium cholate $150 \mu \mathrm{g}$; and $0.2 \mathrm{U}$ of enzyme in $200 \mu \mathrm{l}$ of $50 \mathrm{mM}$ acetate buffer, $\mathrm{pH} 5.0$ for $18 \mathrm{~h}$. For molecular weight determination, laser desorption mass spectrometry (LD-MS) of an isolated ganglioside was performed in the linear mode.

\section{Results}

Gangliosides of na- and a-EAT cells

The content and composition of gangliosides in na- and aEAT cells are shown in Tables 1 and 2, and Figure 1A. As clearly shown, na-EAT cells contained a significant amount of gangliosides. On the other hand, the content of lipid-bound sialic acid in a-EAT cells was only $15.3 \%$ of that in na-EAT cells based on protein content, and accounted for $14.4 \%$ of that in na-EAT cells based on total phosphate content. Qualitative and quantitative analyses of gangliosides were carried out by HPTLC. As shown in Fig. 1, na-EAT cells contain at least 12 different kinds of mono-, di-, and trisialogangliosides, as eluted stepwise by increasing concentration of ammonium acetate in DEAESephadex column chromatography. However, the gangliosides present in a-EAT cells were obtained only from the $0.15 \mathrm{M}$ ammonium acetate fraction. a-EAT cells contained di- and trisialogangliosides, similar to those in na-EAT cells, but a-EAT cells did not contain any monosialogangliosides.

Qualitative analyses of neutral glycolipids in na- and aEAT cells were carried out by HPTLC (Fig. 2). Major glycolipids were recovered in the chloroform:methanol (1:1) fraction by Silica gel column chromatography. In addition, a fraction containing glucosylceramide (Glc-cer) was obtained from the chloroform:methanol (4:1) fraction under our experimental conditions. In contrast to the gangliosides pattern of the two cell lines, the pattern of their neutral glycolipids was similar. Both cells contained the globo series of neutral glycolipids, e.g. Glc-cer, lactosylceramide (Lac-cer), globotriaosylceramide (Gb3) and globoside (Gb4), based on comparison of their migratory rates with those of authentic neutral glycolipids. The intensely stained components migrating faster than Glc-cer which could be non-polar lipids were incompletely separated. They gave a brownish colour rather than the purple colour given by carbohydratecontaining components stained by Orcinol.

Table 1. Content of lipid-bound sialic acid in EAT cells and the extracellular fluid.

\begin{tabular}{llll}
\hline & \multicolumn{3}{l}{ Lipid-bound sialic acid (nmol) } \\
\cline { 2 - 4 } & $\begin{array}{l}\text { per mg } \\
\text { protein }\end{array}$ & $\begin{array}{l}\text { per } 10^{8} \\
\text { cells }\end{array}$ & $\begin{array}{l}\text { per umol of } \\
\text { phosphate }^{\text {a }}\end{array}$ \\
\hline na-EAT & 1.57 & 29.33 & 5.55 \\
a-EAT & 0.24 & 4.11 & 0.80 \\
c/m 1 & 1.53 & 28.21 & 5.25 \\
c/m 2 & 1.48 & 26.85 & 5.08 \\
c/m 10 & 1.28 & 23.09 & 4.44 \\
Ascites fluid & 0.80 & 25.57 & $\mathrm{ND}$ \\
\hline
\end{tabular}

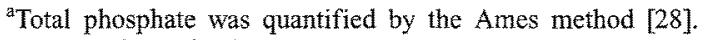

$\mathrm{ND}$, not determined. 
Table 2.Relative content of ganglioside components.

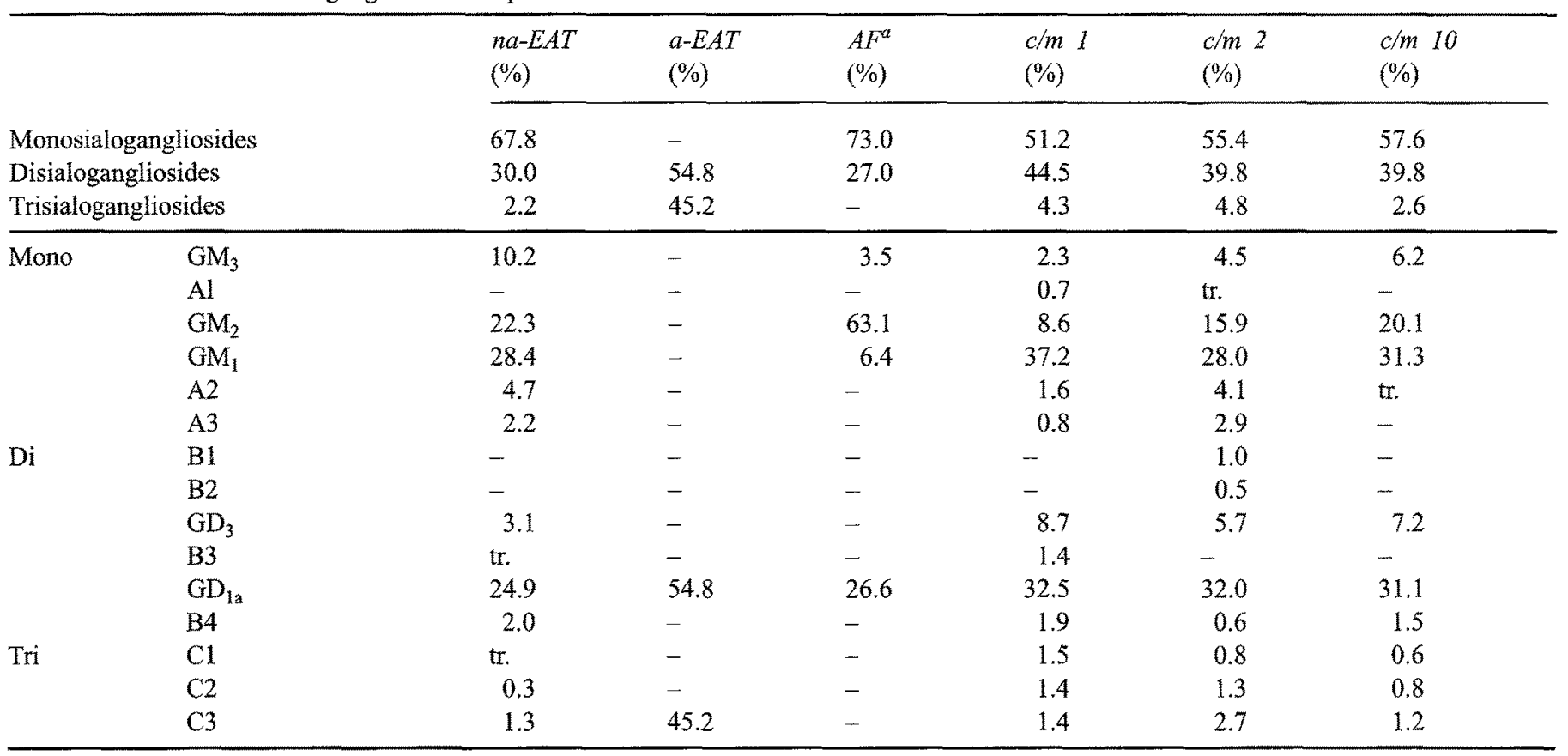

${ }^{a}$ ascites fluid

tr., trace.

Gangliosides of na-EAT cells were further fractionated by preparative TLC and their carbohydrate composition was analysed by Dionex HPLC. The major gangliosides present in na-EAT cells were characterized as GM3, GM2, GM1a, GD3 and GDla, based on the following results. (a) The doublet components having similar HPTLC mobility to GM3 were characterized as GM3, inasmuch as sialidase (Vibrio cholerae) treatment and mild acid hydrolysis converted them to lactosylceramide; (b) the second doublet components were GM2, since they were not hydrolysed by the sialidase and gave neutral glycolipids with the same HPTLC mobility as asialoGM2 following mild acid hydrolysis; (c) the third components were identified as GM1a on the basis of insusceptibility to sialidase - they gave asialo-GM1 following mild acid hydrolysis; (d) the doublet disialogangliosides having HPTLC mobility identical to that of GD3 were characterized as GD3, since sialidase treatment and mild acid hydrolysis converted them to lactosylceramide: (e) four components having HPTLC mobilities similar to that of GDla were characterized as GDla species, inasmuch as they were converted to GM1 and asialo-GM1, following sialidase treatment and mild acid hydrolysis, respectively.

Concerning the structures of $\mathrm{C} 1, \mathrm{C} 2$ and $\mathrm{C} 3$ which were eluted with $0.45 \mathrm{M}$ ammonium acetate in DEAE column chromatography, the results of the sialidase treatment and mild acid hydrolysis showed that they contain the asialo-GM1 backbones, suggesting they are probably GT1b.

A minor monosialoganglioside (A2) migrating slightly slower than GM1 (RGM1 0.96 in chloroform:methanol:0.25\% KCl, 50:40:10) was isolated. This A2 ganglioside was resistant to sialidase treatment. $\mathrm{A} 2$ was converted to a neutral glycolipid with the same TLC mobility as asialo GM1 following mild acid hydrolysis. LD-MS of A2 showed several fragments from the carbohydrate chain. The ions at 1264, 1555, and 1741 corresponded to molecular weights of asialo GM1, GM1 and $\mathrm{A} 2$, respectively. After ceramide-glycanase treatment, the migration of released oligosaccharide from $\mathrm{A} 2$ on HPTLC (in n-butanol:acetic acid:water, 2:1:1) was slower than that of authentic GM1. These results suggest that A2 contains an additional carbohydrate residue attached to GM1. However A2 was resistant to the enzymatic action of $\alpha$-L-fucosidase from bovine kidney. Since the amounts of available materials were low, further structural analyses of A1-3 and B1-4 could not be carried out.

Since a-EAT cells contain $\alpha-2,6$-linked sialic acid on their cell surface glycoconjugates as revealed by their agglutination with the Sambucus nigra (SNA) lectin, we employed an HPTLC overlay procedure to determine if this linkage is present on glycolipids. Initially, we used horse radish peroxidase (HRP) labelled slug lectin Limax flavas agglutinin (LFA), which reacts with sialic acid in any linkage [23], following TLC separation. Gangliosides 


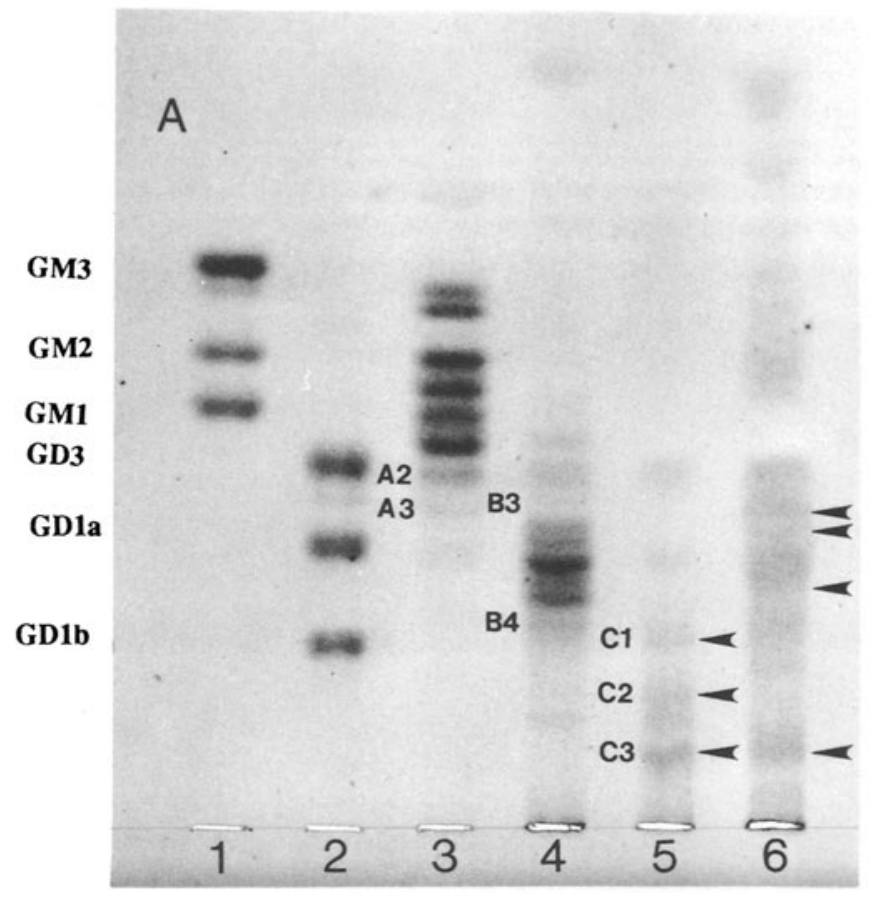

B

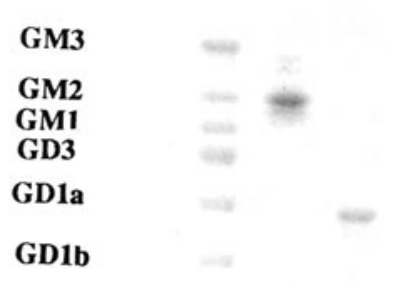

$\begin{array}{lll}1 & 2 & 3\end{array}$

Figure 1. Thin-layer chromatograms of gangliosides from EAT cells and ascites fluid. (A) Lane 1, authentic monosialogangliosides (from top to bottom: GM3, GM2, GM1); Lane 2, authentic disialogangliosides (from top to bottom: GD3, GDla, GD1b); Lanes 3-5, gangliosides eluted by increasing concentration of ammonium acetate in DEAE-Sephadex column chromatography of glycolipids from Folch's upper phase of na-EAT cells; Lane 3, $0.015 \mathrm{M}$; Lane 4, $0.15 \mathrm{M}$; Lane $5,0.45 \mathrm{M}$; Lane 6, gangliosides from a-EAT cells. (B) Lane 1, authentic gangliosides of GM3, GM2, GM1, GD3, GD1a and GD1b (from top to bottom); Lane 2, monosialogangliosides fraction from the ascites fluid; Lane 3, disialogangliosides fraction from the ascites fluid. The solvent system for TLC was chloroform:methanol:0.25\% $\mathrm{KCl}$ in water $(50: 40: 10, \mathrm{v} / \mathrm{v} / \mathrm{v})$. Gangliosides were visualized with the resorcinol$\mathrm{HCl}$. Arrows indicate the resorcinol positive bands. A2, A3, $\mathrm{B} 3, \mathrm{~B} 4, \mathrm{Cl}, \mathrm{C} 2$ and $\mathrm{C} 3$ are minor gangliosides of unknown structure.

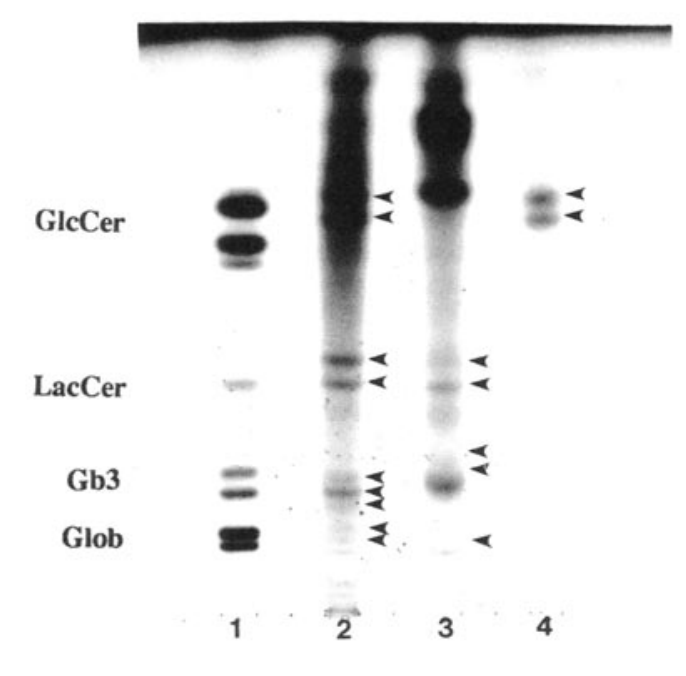

Figure 2. Thin-layer chromatogram of neutral glycolipids in Folch's lower phase from na- and a-EAT cells. Neutral glycolipids were fractionated by stepwise elution with chloroform:methanol in Silica gel column chromatography as described under 'Materials and methods'. Lane 1, authentic neutral glycolipids of GlcCer, LacCer, Gb3 and Glob (from top to bottom); Lane 2, neutral glycolipids recovered from chloroformmethanol (4:1 and 1:1) of na-EAT cells; Lanes 3 and 4, neutral glycolipids from a-EAT cells; Lane 3, chloroform:methanol (1:1); Lane 4, chloroform:methanol (4:1). The solvent system for TLC was chloroform:methanol:water $(65: 25: 4)$. The bands were visualized with the copper-phosphoric acid reagent. Arrows indicate the orcinol positive bands.

in both cell lines were detected by this HPTLC lectin overlay method using HRP-LFA. However, no positive reaction of gangliosides with HRP-SNA was detected in either na- or a-EAT cells, suggesting the absence of $\alpha$ 2,6-linked sialic acid in gangliosides in both cell lines; the HRP-SNA lectin was shown to react with fetuin which contains $\alpha$-2,6-linked sialic acid.

\section{Characterization of gangliosides in ascites fluid}

As shown in Table 1, the content of lipid-bound sialic acid in the extracellular fluid from na-EAT cells was $0.80 \mathrm{nmol}$ per mg protein. The ganglioside pattern of ascites fluid, as shown in Fig. 1B, was extremely simple as compared to that of the cell fraction. The two major gangliosides comigrated with standard GM2 and GD1a. Further characterization by sialidase treatment and mild acid hydrolysis confirmed this assignment.

As a control for the gangliosides present in ascites fluid from EAT cells-bearing mice, gangliosides in the ascites fluid present in mice containing no tumour were prepared. The ascites fluid was obtained from mice which were injected intraperitoneally with thioglycollate (TG). Several kinds of monosialogangliosides such as GM3, GM2 and GM1 were detected. Among them GM1 was the major ganglioside constituent of the ascites fluid from 
non tumour-bearing mice. GM1 present in the ascites fluid might be related to the GM1 present in macrophages that is the predominant ganglioside of TGstimulated mouse macrophage [24]. The ascites fluid did not contain any disialogangliosides. Besides monosialogangliosides, a few resorcinol-positive bands were also detected in the region of trisialogangliosides. Further fractionation of the gangliosides was not attempted due to the low amount of available material.

\section{Gangliosides in $\mathrm{c} / \mathrm{m}$ EAT cells}

The ganglioside profiles of $\mathrm{c} / \mathrm{m} 1$ and $\mathrm{c} / \mathrm{m} 2$ cells are shown in Fig. 3. Although the ganglioside content of aEAT cells was extremely low, the levels of lipid-bound sialic acid in $\mathrm{c} / \mathrm{m} 1$ cells returned to that of na-EAT cells (Table 1). One of the significant differences in the ganglioside patterns was that GM1 accumulated in $\mathrm{c} / \mathrm{m}$ 1 cells. It is possible that the $\beta$-galactosidase present in

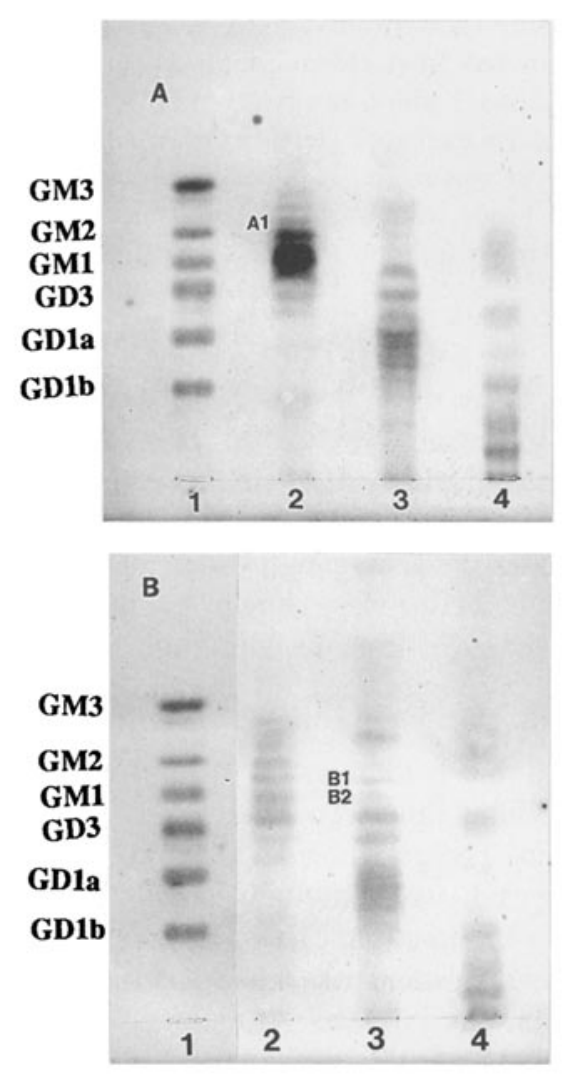

Figure 3. Thin-layer chromatograms of gangliosides from $\mathrm{c} / \mathrm{m} 1$ (A) and $\mathrm{c} / \mathrm{m} 2$ (B) EAT cells. Lane 1, authentic gangliosides of GM3, GM2, GM1, GD3, GD1a and GD1b (from top to bottom); Lane 2, monosialoganglioside fraction; Lane 3, disialoganglioside fraction; Lane 4, trisialoganglioside fraction. The solvent system for TLC was chloroform:methanol:0.25\% $\mathrm{KCl}$ in water $(50: 40: 10$, $\mathrm{v} / \mathrm{v} / \mathrm{v})$. Gangliosides were visualized with resorcinol-HCl. A1, B1 and $\mathrm{B} 2$ are minor gangliosides of unknown structure. ascites fluid might affect the production of GM1 from GM2 [25]. At this point, it is difficult to decide whether GM2 in ascites fluid is a precursor for GM1. Ten consecutive passages in mice were earried out and the gangliosides extracted from the $\mathrm{c} / \mathrm{m} 10$ cells, as shown in Fig. 4. The general trend observed with successive passages was a reduction in the proportion of disialogangliosides with a concomitant increase in the percentage of monosialogangliosides. In addition, the relative content of GD3 in c/m 1 cells was highest among the cell lines in this study. The GD3 content decreased with successive passages, with an increase in GM3. The pattern of $\mathrm{c} / \mathrm{m} 1$ cells was intermediate between na- and a-EAT cells. The characterization of gangliosides in $\mathrm{c} / \mathrm{m} 2$ cells shifted to that present in na-EAT cells.

A preliminary experiment regarding the ability of $\mathrm{c} / \mathrm{m}$ EAT cells to adhere to tissue culture plastic was conducted. Under the experimental conditions described, na-EAT cells did not attach to tissue culture plastic. In contrast, $-70 \%$ of $\mathrm{c} / \mathrm{m} 1$ and $\mathrm{c} / \mathrm{m} 2$ EAT cells attached to tissue culture plastic $18 \mathrm{~h}$ after plating. It required 2 and 3 days, respectively, for $\mathrm{c} / \mathrm{m} 1$ and $\mathrm{c} / \mathrm{m} 2$ EAT cells to spread on plastic, while it required $2-3 \mathrm{~h}$ for a-EAT cells to spread. Even after 10 passages in mice, cells had not completely lost their ability to adhere, since approximately $50 \%$ of $\mathrm{c} / \mathrm{m} 10$ EAT cells adhered 5 days after plating. Although $\mathrm{c} / \mathrm{m} 10$ EAT cells attached and were cultured for 2 weeks, they did not spread on plastic. Thus $\mathrm{c} / \mathrm{m}$ EAT cells showed different attachment and spreading properties from those of a-EAT cells.

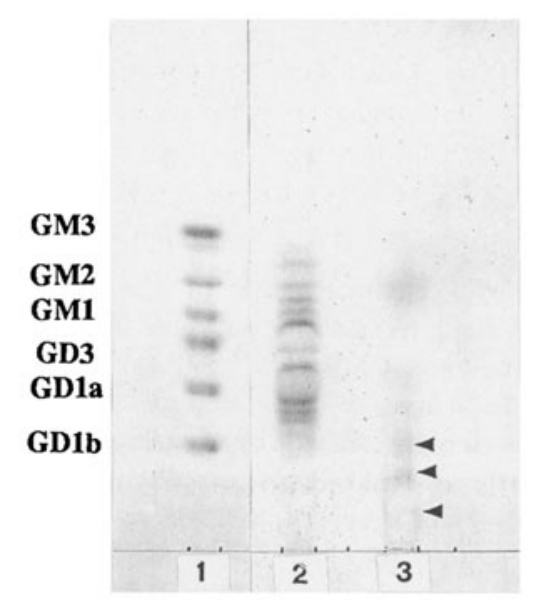

Figure 4. Thin-layer chromatogram of gangliosides from $\mathrm{c} / \mathrm{m} 10-$ EAT cells. Lane 1, authentic gangliosides of GM3, GM2, GM1, GD3, GD1a and GD1b (from top to bottom); Lane 2, mono- and disialogangliosides fraction; Lane 3, trisialoganglioside fraction. The solvent system for TLC was chloroform:methanol:0.25\% $\mathrm{KCl}$ in water $(50: 40: 10, \mathrm{v} / \mathrm{v} / \mathrm{v})$. Gangliosides were visualized with resorcinol-HCl. Arrows show the resorcinol positive bands. 


\section{Discussion}

Our data show that the pattern of gangliosides present in a-EAT cells differed significantly from that in na-EAT cells, both qualitatively and quantitatively. a-EAT cells did not contain monosialogangliosides and the gangliosides present were characterized as GDla and GTlb. Several studies suggested that di- or trisialogangliosides such as GDla and GT1b of tumour-cell origin may assist the tumour in the development of metastatic capacity [26]. The role of gangliosides present in a-EAT cells remains unclear.

Isolation of gangliosides present in ascites fluid from tumour-bearing mice was performed to determine if the ganglioside pattern difference in the two cell lines is due to differences in their growth environment. GM2 and GDla were found to accumulate in the ascites fluid fraction. This observation differed from the ganglioside composition of thioglycollate-stimulated ascites fluid, which contains at least six kinds of monosialigangliosides and no disialoganglioside. In a previous study on the role of GM2, it was suggested that the growth rate and size of human melanoma are proportional to the content of GM2 in the $\log$ phase of the tumour growth [27]. However, the role of gangliosides in tumour-bearing mouse ascitic fluid is at present unknown. The tumour bearers' serum ganglioside profile closely resembled that of tumour tissue and differed from that of normal serum [27]. The significant amount of GM2 in tumour bearing mice ascites fluid might be of host origin, produced as a result of host-tumour interaction. Additionally, GM2 and GD1a, which are characteristic gangliosides in ascites fluid in tumour-bearing mice, might be related to the formation of EAT cell gangliosides.

We analysed gangliosides in a-EAT cells that were reinjected into the murine peritoneal cavity to determine whether there was a change in the ganglioside pattern found in na-EAT cells as influenced by a change in the physiological milieu of the murine peritoneal cavity. Our findings with respect to the contents and patterns of gangliosides in EAT cells are as follows: (i) the content of lipid-bound sialic acid in the a-EAT cell line is $c a$. $15 \%$ of that in either na-EAT or $\mathrm{c} / \mathrm{m}$ cell lines; (ii) the level of lipid-bound sialic acid was significantly elevated for $\mathrm{c} / \mathrm{m} 1$ cells compared to a-EAT cells; (iii) it was necessary to passage a-EAT cells through only two successive animals before they reverted to the ganglioside patterns characteristic of na-EAT cells. An alternate interpretation is that a selection process may have occurred. In contrast to the glycosylation of gangliosides in EAT-cell lines, our previous studies showed that a change in $\mathrm{c} / \mathrm{m}$ cells glycosylation pattern appeared after 25 passages in that their reactivity with lectins and the extent of glycosylation of their glycoproteins resembled na-EAT cells [3]. These results suggest that a stimulation factor for tumour cell-associated ganglioside synthesis may exist in the murine peritoneal cavity, and that the sialylation of glycolipids might be controlled by an independent sialyltransferase, distinct from that of glycoprotein sialylation. Other investigators showed that the extracellular environment can affect ganglioside metabolism $[29,30]$. The study on the interaction of the gangliosides present in the peritoneal cavity with those in the tumour cells is a subject for further investigation.

Another purpose of this study was to determine whether $\alpha-2,6-$ linked sialic acid is present on glycolipids and/or glycoproteins, inasmuch as a-EAT cells contain this linkage as revealed by their agglutination assay with the SNA lectin. Both ECL Western blotting products (Amersham Life Science) and a combination of peroxidase with 4-chloronaphthol were used for the detection of sialic acid following the separation of gangliosides on TLC and the reaction with the lectin. However, no positive reaction of the ganglioside with HRP-SNA was detected in either na- or a-EAT cells. Although our previous work showed a-EAT cells exhibited a selective increase of two- to five-fold over na-EAT cells in the activity of $\alpha-2,6-\mathrm{N}$-linked sialyltransferase activity, there is no correlation between the expression of $\alpha-2,6-$ sialyltransferase activity and the presence of $\alpha-2,6-$ sialylated glycolipids in this study, as previously reported in the literature [10].

A search of the literature indicates that there does not appear to be a good correlation between cell adhesion and content and nature of gangliosides [14]. No direct relationship has been demonstrated in this study. As noted in the result section, our preliminary experiments indicate that $\mathrm{c} / \mathrm{m}$ cells exhibit attachment properties different from those of a-EAT cells. We plan to examine in more detail the ability of $\mathrm{c} / \mathrm{m}$ cells to adhere to and spread on various components of the extracellular matrix. This could be a good system to gain insight into the metastatic properties of tumour cells.

\section{References}

1. Eckhardt AE, Goldstein IJ (1983) Biochem 22: 5280-89.

2. Eckhardt AE, Goldstein IJ (1983) Biochem 22: 5290-97.

3. Knibbs RN, MacCallum DK, Lillie JH, Goldstein IJ (1994) Glycobiology 4: 419-28.

4. Song Z, Varani J, Goldstein IJ (1993) Int J Cancer 55: 1029-35

5. Wang W-C, Cummings RD (1988) J Biol Chem 263: 4576-85.

6. Knibbs RN, Goldstein IJ, Ratcliffe RM, Shibuya N (1991) $J$ Biol Chem 266: 83-88.

7. Hayes CE, Goldstein IJ (1974) J Biol Chem 249: 1904-14.

8. Shibuya N, Goldstein IJ, Broekaert WF, Nsimba-Lubaki M, Peeters B, Peumans WJ (1987) J Biol Chem 262: 1596-1601.

9. Mostafapour MK, Goldstein IJ (1993) Arch Biochem Biophys 303: $255-59$ 
10. Dall'Olio F, Malagolini N, Stefano GD, Ciambella M, SerafiniCessi F (1991) Int $J$ Cancer 47: 291-97.

11. Holmes EH, Hakomori S (1983) J Biol Chem 258: 3706-13.

12. Hakomori S (1981) Ann Rev Biochem 50: 733-64.

13. Hakomori S (1984) Ann Rev Immunol 2: 103-26.

14. Hakomori S (1985) Cancer Res 45: 2405-14.

15. Ledeen RW, Yu RK (1982) Methods Enzymol 83: 139-91.

16. Saito T, Hakomori S (1971) J Lipid Res 12: 257-59.

17. Ariga $\mathrm{T}$, Macala LJ, Saito $M$, Margolis RK, Greene LA, Margolis RU, Yu RK (1988) Biochem 27: 52-58.

18. Svennerholm L (1957) Biochim Biophys Acta 24: 604-11.

19. Svennerholm L (1956) J Neurochem: 1: 42-53.

20. Hiraiwa N, Fukuda Y, Imura $H$, Tadano-Aritomi $K$, Nagai $K$, Ishizuka I, Kannagi R (1990) Cancer Res 50: 2917-28.

21. Ariga T, Kobayashi K, Kuroda Y, Yu RK, Suzuki M, Kitagawa H, Inagaki F, Miyatake T (1987) J Biol Chem 262: 14146-53.
22. Li S-C, DeGasperi R, Muldrey JE, Li Y-T (1986) Biochem Biophys Res Commun 141: 346-52.

23. Knibbs RN, Osborne SE, Glick GD, Goldstein IJ (1993) J Biol Chem 268: 18524-31.

24. Mercurio AM, Schwarting GA, Robbins P (1984) J Exp Med 160: $1114-25$.

25. Yagi F, Eckhardt AE, Goldstein IJ (1990) Arch Biochem Biophys 280: 61-67.

26. Saha S, Ghosh A (1990) Int $J$ Cancer 46: 691-94.

27. Saha S, Chattopadhyay U (1988) Int $J$ Cancer 41: 432-35.

28. Ames BN (1966) Methods Enzymol 8: 115-18.

29. Fredman P, Mansson JE, Bigner SH, Wikstrand $\mathrm{CJ}$, Bigner DD, Svennerholm L (1990) Biochim Biophys Acta 1045: 239-44.

30. Li R, Gage D, Ladisch S (1993) Biochim Biophys Acta 1170: $283-90$. 